\title{
Vaginal bacteria flora concurred with vaginal sponges in black Iraqi goats
}

\author{
A.F. Majeed, H.M. Al-Rawi, S.M.A. Al-Kubaisi and T.M.N. Al-Jumaily
}

College of Veterinary Medicine, Al-Anbar University, Al-Anbar, Iraq

\begin{abstract}
The aim of this study was to identify the vaginal bacteria flora in black Iraqi goats subjected to estrus synchronization. Sixteen multiparous black Iraqi goats presented in the farm of the College Veterinary Medicine, Al-Anbar University, were included in this study, during the breeding season, from May 2011 to July 2011. The ages of the animals rwere 2-4 years. A polyurethane sponge containing $20 \mathrm{mg}$ of micromsed cronolone (fluorogestone acetate progestagen) was inserted in the vagina for 14 days. Standard bacteriological procedures were performed on vaginal mucus swabs obtained before application of the sponges and at sponges withdrawal. Results of this study revealed that the most bacterial flora was Gram positive Bacilli before insertion of sponges, while most of Gram negative Bacilli were present after sponges withdrawal. Bacterial culture of vaginal swabs taken before insertion of sponges showed 8 isolates $(50 \%) \mathrm{G}^{-}$and 8 isolates $(50 \%) \mathrm{G}^{+}$, while after withdrawal of sponges the bacterial culture showed 10 isolates $\mathrm{G}^{-}(45.4 \%)$ and 12 isolates $(54.6) \mathrm{G}^{+}$. The most prevalent bacteria isolated were S. aureus (10 isolates) $26.3 \%$. E. coli (6 isolates) $15.8 \%$, P. vulgaris (6 isolates) $15.8 \%$, C. (4 isolates) $10.5 \%$ and other bacteria where having 2 isolates $5.2 \%$ for each one includes, Entercoccus fecalis, Entrococcus, Entrobacter, Klebsiella pneumonia, Pseudomonas aeroginosa and Salmonella. In conclusion, using progestagen impregnated sponges in the vagina for estrus synchronization could stimulate inflammation of the vaginal mucous membrane and increase of bacterial infection.
\end{abstract}

Keywords: Vaginal flora; Vaginal sponges; Goats.

Available online at http://www.vetmedmosul.org/ijvs

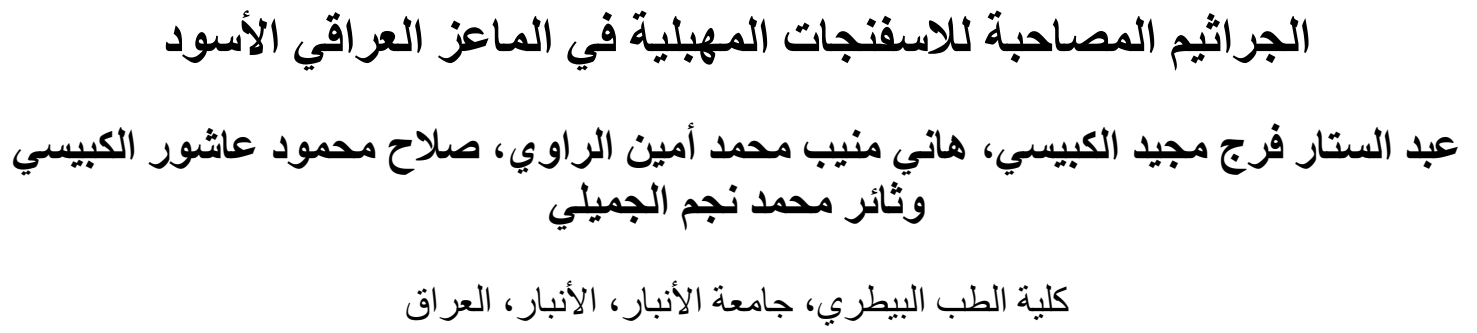

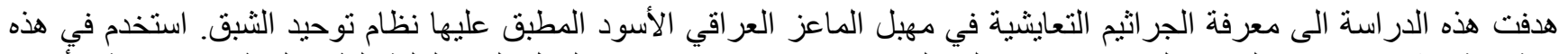

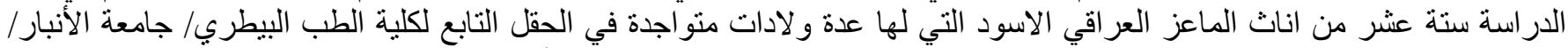

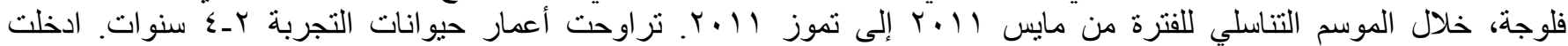

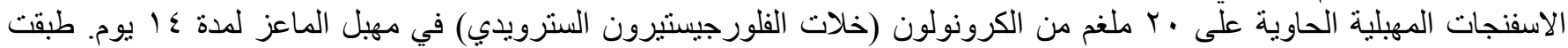

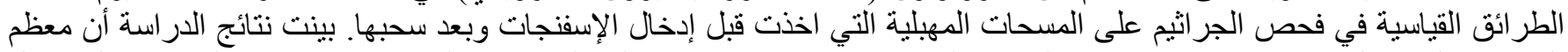

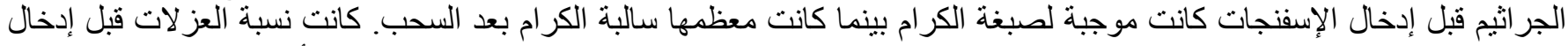

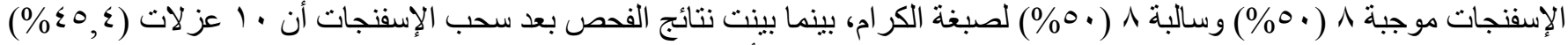

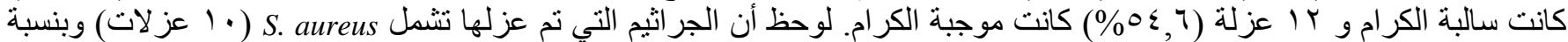

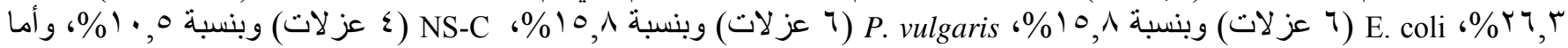

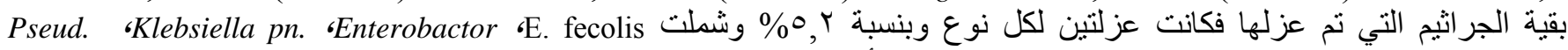
aurogenosa توحيد الثبق قد يؤدي إلى تنشيط حدوث التهابات مخاطية المهبل وزيادة الإصابة بالجر الثيم. 


\section{Introduction}

Several protocols have been reported to be used for estrus synchronization in goats (1-5). Intravaginal sponges impregnated with progestagens being the most commonly used. These sponges are manufactured from different substances that can create changes in the vaginal environment (5). Vaginitis was the common reproductive disorder of small ruminant genital tract. It is caused by secondary bacterial invaders, mainly, E. coli species, and gram positive bacteria (6). The aim of this study was to identify the vaginal bacteria flora in black Iraqi goats subjected to estrus synchronization.

\section{Materials and methods}

The study was conducted on sixteen multiparous black Iraqi goats, presented in the farm of College of Veterinary Medicine, Al-Anbar University, Fallouja, during the breeding season, from May 2011 to July 2011. The age of the animals ranged 2-4 years.

A polyurethane sponge containing $20 \mathrm{mg}$ of micromsed cronolone (Fluorogestone Acetate Progestagen) was inserted in the vagina of the goats for a period of 14 days.Vaginal swabs were taken using aseptic techniques before insertion of the sponges and at sponges withdrawal. The samples were transported to the diagnostic lab of College of Veterinary Medicine, Al-Anbar University, Fallouja. Within half an hour and then cultured on Blood Ager Nutrient ager, MacConkey ager and then cultured on selective media. The plates were incubated at $37^{\circ} \mathrm{c}$ and examined daily for bacterial growth, for a period of 3 days. Genera of bacteria were identify according to the basis of colony characteristics gram staining, microscopic morphology and biochemical test, which including, Oxidase, Catalase, O/F, Indol, MR, VP, Citrate, TSI, $\mathrm{H}_{2} \mathrm{~S}$ and Gas production. Genera were classified according to Quinn (7).

\section{Results and discussion}

All vaginal swabs showed bacterial growth. The total number of isolates was 38. The predominant bacteria isolated were gram positive $\left(\mathrm{G}^{+}\right)$which constitute $57.9 \%$ $\left(22 / 38\right.$ isolates), while the gram negative $\left(\mathrm{G}^{-}\right)$bacteria showed $42.1 \%$ (16/38 isolates). Similar observations have been made by ( 3 and 5 ). It has been reported that presence of a foreign body, such as sponge in the vagina stimulated bacterial growth and local mucous secretion during sponge treatment and these changes create a localized inflammation $(1,8)$.

Bacterial culture of the vaginal swabs before insertion showed $8(50 \%)$ isolates $\mathrm{G}^{-}$and $8(50 \%)$ isolates $\mathrm{G}^{+}$, while after withdrawal of sponges the bacterial culture showed 10 isolates $\mathrm{G}^{-}(45.4 \%)$ and 12 Isolates (54.6) $\mathrm{G}^{+}$.

The most prevalent bacteria isolated were $S$. aureus (10 Isolates) $26.3 \%$. E. coli (6 Isolates) $15.8 \%, P$. vulgaris (6 Isolates) $15.8 \%$, Coagulase Negative Staphylococcus (CN.S.) (4 Isolates) $10.5 \%$ and other bacteria where having 2 isolates $5.2 \%$ for each one includes, Entercoccus fecalis, Entrococcus, Entrobacter, Klebsiella pneumonia, Pseudomonas aeroginosa and Salmonella.

Similar observation has been reported by others (1-5). Progesterone suppresses specific components of the immune system and natural killer cell activity, while it has a mainly positive influence on other non specific components $(9,10)$. It is also reported that hormonal changes status such as estrus cycle or synchronization could be effect on vaginal bacterial population especially when progesterone levels were high (1).

It could be concluded from the results of this study that using of progestagen impregnated sponges in the vagina for estrus synchronization could stimulate inflammation of the vaginal mucous membrane and increase of bacterial infection.

\section{References}

1. Suarez, G., Zunino, P., Carol, H. and Ungerfeld, R., 2006. Changes in the aerobic vaginal bacterial mucous load and assessment of susceptibility to antibiotics after treatment with intravaginal sponges in anestrus ewes. Small Rum. Res., 63:39-43.

2. Yesilmen, S., Ozyurtlu, N., Kucukaslan, I. and Altan, F., 2008. The effect of progesagen on the changes of the vaginal flora arsing from Intravaginal sponge treatment and susceptibility of the vaginal flora to antibiotics in ewew. J. Anim. Vet. Advances, 7:11): 1418-1421.

3. Martins, L. T., Neto, P. C. S., Neto, S. G., Rauber, L. P., Bertolini, M., Vieira, A. D. and Mezzalira, A., 2010. Microbiological and functional evaluation of an alternative device $(\mathrm{OB})^{\circledR}$ for estrous synchronization in ewes. Cienica- Rural, Santa Maria, 40: (2). 389-395.

4. Arias- Alvarez, M., Garcia-Garcia, R. M., Torres-Rovira, L., Gonzalez- Bulness, A., Rebollar, P. G., and Lorenzo, P.L., $201{ }^{\prime} 0$. Influence of hormonal and non hormonal estrus synchronization methods on follicular and oocyte quality in primiparous lactating does at early postpartum period. Theriogenology, 73:26-35.

5. Manes, J., Fiorentino, M.A., Kaiser, G., Hobor, F., Alberio, R., Sanchez, E. and Paolicchi, F., 2010. Changes in the aerobic vaginal flora after treatment with different intravaginal devices in ewes. Small Rum. Res., 94: 201-204.

6. Sargison, N.D., Howie, F., Mearans,R., Penny, C.D., and Foster, G., 2007. Shiga toxin- producing E. coli as a perennial cause of abortion in a closed flock of Suffolk ewes. Vet. Rec., 160: 875-876.

7. Quinn, P.J., Carter, M.G., Markey. B. and Carter, G.R. (2002). Clinical (Veterinary microbiology) M. Wolfe, London.

8. Motlomelo, K.C., Greyling, J.P.C. and Schwalbach, L.M.J., 2002. Synchronization of oestrus in goats: the use of different progestagen treatments. Small Rum. Res., 45: 45-49.

9. Pineda, M.H. 2003. Female reproductive system. In: Pineda, M.H.(Ed.). Veterinary Endocrinology and reproduction, Iowa state press, Iowa, PP. 293-241. ISBN: 0-8138-1106-6.

10. Scheibl, P. and Zerbe, H., 2000. Effect of progesterone on the immune system in consideration of bovine placental retention. Dtsch. Tierar Woch., 107: (6): 221-227. 